\title{
Child Soldiers in Myanmar
}

\author{
Remaining Challenges and Policy Implications
}

\author{
Kai Chen \\ School of International Relations \\ Xiamen University \\ Xiamen, China
}

\begin{abstract}
This article reviews the current situation of child soldiers in Myanmar, explores the challenges facing the stakeholders' efforts to prevent Child Soldier in this country, then analyzes the relevant policy implications in the foreseeable future.
\end{abstract}

\section{Keywords-Child Soldier; Myanmar; Public-private Partnership}

\section{INTRODUCTION}

Child Soldier is one of most crucial ways in which children are affected by wars or armed conflicts. Historically, violence against children occurs from time to time. Children have not only been targeted in wars or armed conflicts; more disturbingly, they are being recruited as child soldiers in many parts of the world, who are defined as "any individual under the age of 18 who is a member of or attached to any regular or irregular armed group, whether or not an armed conflict exists". [1] They are recruited into the armed forces, and often are exposed to death and other forms of violence.

At present, the forced displacement of over 60 million people worldwide, half of them are children. [2] Unfortunately, many displaced children become child soldiers. According to the Secretary-General of the United Nations, at the very least, there are eight counties recruiting children into their armed forces, including Afghanistan, Chad, Myanmar, Somalia, South Sudan, Sudan and Yemen. [3] Until now, the situation of child soldiers in Myanmar is largely under-reported.

After the independence of Myanmar in 1948, Child Soldier has accompanied the long-lasting asymmetric armed conflicts between the Myanmar Army and the ethnic-based militias, the latter control sizeable territories of this country. [4] In Myanmar, the majority of the child soldiers are displaced children, HIV/AIDS orphans and trafficked victims. In many cases, loss of family, abuse, discrimination, and violence, which these vulnerable children faced as a consequence of armed conflicts, facilitated their participation in the armed conflicts.

In addition to the Myanmar Army, the UN secretarygeneral has named seven of the country's ethnic-based militias as persistent perpetrators of Child Soldier, that is, the Democratic Karen Benevolent Army, Kachin Independence Army, Karen National Liberation Army, Karen National
Liberation Army Peace Council, Karenni Army, Shan State Army South, and United Wa State Army. [5]

In Myanmar, most of the child soldiers who survived through the bloody combats are good at responding to various circumstances and making decisions with or without commander's order. For both the ethnic-based militias and the Myanmar Army, child soldiers would expand their power to some extent. The recruiters often targeted "working and unaccompanied children at workplaces, bus and train stations, ferry terminals and markets and in the streets, and orphans and non-working children in home villages and wards". [6]

\section{CURRENT SITUATION}

To prevent more children from being involved in armed conflicts, the Myanmar government has been make policy co-ordinations with the other stakeholders, such as UNICEF (United Nations International Children's Emergency Fund), UNHCR (United Nations High Commissioner for Refugees), the International Committee for the Red Cross, and the World Food Program etc.

In June 2012, an action plan to end and prevent the recruitment of children by the Tatmadaw (Myanmar Army) was signed between the Government of Myanmar and the country task force, which recommits to end Child Soldier. The action plan contains a set of commitments to be pursued by the Government and the country task force over an initial 18-month time frame. The commitments include "the systematic identification, registration and release of all children under the age of 18 recruited and used in the Tatmadaw (Myanmar Army); the reintegration of such children into their communities; the strengthening of recruitment procedures to ensure the prevention of further child recruitment by the Tatmadaw (Myanmar Army); public awareness-raising on prevention and release; training and capacity-building for the Tatmadaw (Myanmar Army) on international human rights, humanitarian law and child protection; and the strengthening of disciplinary action against perpetrators". [7]

Since then, Myanmar has been taking a series of countermeasures. For example, "over 12,000 members of the armed forces have received training on the action plan". [8] Myanmar Army has promised to undertake "a series of timebound measures" to release all child soldiers, such as reforming "age verification mechanisms, recruitment 
procedures and accountability mechanisms to ensure children are not recruited and used as soldiers in state forces".[9] Until March 2016, Myanmar Army "has released 744 underage recruits in 12 batches".[10]

\section{REMANING CHALLENGES}

The current situation of governing child soldiers in Myanmar seems barely satisfactory. Despite the mentionedabove encouraging developments, many challenges remain and that further efforts need to be undertaken by the stakeholders to end violations and abuses against children. In the opinion of the author, there are five remaining challenges.

First, to some degree, Child Soldier in Myanmar Army, border guard forces and ethnic-based militias continues. For example, according to a 29-page report issued by the UKbased NGO - Child Soldiers International, some military officers and civilian brokers "continue to use deliberate misrepresentation to entice new recruits, including children".[11] Not surprising, many victims of Child Soldier were reluctant to report their cases to the International Labour Organization (ILO) and the UN Country Task Force on Monitoring and Reporting (UNCTFMR), "for fear of jeopardizing the peace process or out of fear for their own security". [12]

Second, it's hard for the national and local authorities to locate the child soldiers. The child soldiers' names were deliberately altered, this make it more difficult to trace their locations. In addition, the dates of birth of the child soldiers "would almost certainly have been altered, to make them appear over 18”. [13]

JFor the Myanmar Army, the identification of children has been proceeding slowly. There are several challenges faced in identifying children and verifying ages, "particularly the difficult and time-consuming process of discovering falsified documents and tracing authentic age-verification documents, noting that many people do not have original versions of key documentation such as birth certificates, family lists or school leaving certificates to enable prompt and proper verification".[14]

Third, it is of concern that arrests of underage recruits who are labeled as "absent without leave" or "deserters" continued. Some "deserters" are subjected to long-term imprisonment while others live in hiding and are unable to pursue a normal life for fear of arrest and detention. [15]

In general, the rehabilitation of former child soldiers must be supported by long-term financial resources. Given the stakeholders lack of financial resources, the former child soldiers are often vulnerable to being recruited again. When they return to the battlefield, they would become victims of landmines, exploded ordnance, improvised explosive devices, mortar and rocket-propelled grenade attacks, and cross-fire between ethnic-based militias and the Myanmar Army.

Fourth, there were little direct dialogues between the NGOs and the ethnic-based militias, owing to access restrictions by the Government in conflict-affected ceasefire and non-ceasefire areas. Taking note of the security situation, there is continued lack of full and unimpeded access in contested and ceasefire areas is an impediment to providing essential humanitarian assistance for children. The ongoing conflict in Kachin State and Northern Shan State has resulted in the displacement of more than 100,000 people. Many displaced persons have resided in camps for more than four years. National and local community and civil society groups, often with limited resources and capacity, continue to provide much-needed assistance in these areas.[16] In many cases, children have been victims of Child Soldier inside and around refugee camps or camps for internally displaced persons.

Fifth, concerning the children not involving armed conflicts or skirmishes as child soldiers, they might be even more vulnerable than the former ones. It's reported that "one in five children in Myanmar aged 10-17 go to work instead of school", and "the opening up of the economy since 2011 has triggered a spike in demand for labour". [17] Due to the mentioned-above challenges, all the stakeholders can not guarantee rapid responses for vulnerable children in the short term, let alone strengthening a protective mechanism for vulnerable children in the long term.

\section{POLICY IMPLICATIONS}

In March 2016, Myanmar's first civilian President since 1962, Mr Htin Kyaw took power.[18] For the new government, the remaining challenges require new approaches and partnerships that draw on the expertise of the private sector. There is urgently needed to establish a publicprivate partnership among the stakeholders, which has a significant role to play in governing Child Soldier in the long run.

For the international NGOs and local NGOs, they should cooperate with the Myanmar government, and strengthen the governmental monitoring, reporting, prevention and response activities regarding Child Soldier, through raising awareness and building understanding, capacity and confidence among the stakeholders.

For the Myanmar government, "increasing amounts of private resources were being directed to developmentoriented public-private partnerships". Many stakeholders have been calling upon "the official and private sectors to better integrate public-private partnerships into the structuring and delivery of aid programmes, and to work towards scaling up their use and strengthen their implementation".[19]

Through public-private partnership, all the stakeholders could strengthen recruitment procedures, age verification mechanisms and independent monitoring and oversight of all armed forces.[20] More new prevention measures should be implemented, such as filming of key aspects of the recruitment process in the four principal recruitment units of the Myanmar Army (i.e., Yangon, Mandalay, Shwebo and Magway); fingerprinting all would-be recruits; circulating the names of rejected recruits to headquarters and to all recruitment units to prevent re-recruitment of child soldiers elsewhere; and establishing special panels of officers from 
the recruitment units and training schools to "carry out additional age and willingness checks". [21]

It's necessary to ensure compliance of ethnic-based militias with the current child protection arrangements. For instance, all the non-State armed groups should include the protection of children affected by armed conflict, including "the most vulnerable having access to improved education, health care and livelihoods", as an important aspect of ceasefire negotiations and peace talks. [22]

With regard to the former child soldiers accused of criminal acts should be treated "in compliance with due process and juvenile justice standards", and "there should be no capital punishment or life imprisonment for children". [23] The Myanmar Army should "Cease with immediate effect the arrest, the harassment and the imprisonment of children or adults over the age of 18 who were recruited as minors, for desertion and/or attempting to leave the army, and ensure their swift and unconditional release". [24]

It's critically important to establish a child-protection unit with the Myanmar Army, which "should be trained how to address child and youth issues in the traumatic postconflict period". This unit should be authorized by the Myanmar Army to get access to the operational regiments and battalions, recruitment units, training schools, regional commands, and other military areas, where child soldiers may be present. Moreover, the child-protection unit needs to be inform to the military personnel at all levels within the Myanmar Army to ensure that the commitment to identify and discharge children from the Myanmar Army is well understood and implemented across all ranks. In other words, any perpetrators should be held accountable, regardless of rank or position. [25]

\section{CONCLUSION}

In short, the significant resources are required to govern Child Soldier in Myanmar, and the establishment of publicprivate partnership should be allocated as a matter of priority. Until they are achieved, the vulnerable children in Myanmar will continue to remain at risk of being child soldiers.

\section{ACKNOWLEDGMENT}

This article is funded by "Fundamental Research Funds for the Central Universities" in China (Project No. 20720151285).

\section{REFERENCES}

[1] Schmidt, A. (2007). "Volunteer Child Soldiers as Reality: A Development Issue for Africa"; New School Economic Review, Vol 2(1), 2007, p.49.

[2] United Nations. 71st plenary meeting Thursday, 10 December 2015, 10 a.m. New York. A/70/PV.71. 10 December 2015.

[3] 'CChild soldiers are boys and girls we collectively failed to protect,'UN Envoy”. M2 Presswire (England). 15 February 2016.

[4] Silverstein, J. "Burma in 1985: A Nation 'On Hold', Southeast Asian Affairs, vol. 13, no. 1, 1986, p.59.

[5] Myanmar (Burma): Burma Army Releases 46 Child Soldiers. Thai News Service (Bangkok, Thailand). 16 March 2016.
[6] UN Security Council. Report of the Secretary-General on children and armed conflict in Myanmar (S/2013/258). 1 May 2013.

[7] UN Security Council. Report of the Secretary-General on children and armed conflict in Myanmar (S/2013/258). 1 May 2013.

[8] United Nations. "7466th meeting Thursday, 18 June 2015, 10 a.m. New York”.S/PV.7466. 18 June 2015.

[9] "Myanmar (Burma)-Child Soldiers: An Ongoing Battle in Burma". Thai News Service (Bangkok, Thailand). January 31, 2015.

[10] "Myanmar army frees 46 child soldiers: state media". Agence FrancePresse. 13 March 2016.

[11] "Myanmar (Burma)-Child Soldiers: An Ongoing Battle in Burma". Thai News Service (Bangkok, Thailand). 31 January 2015.

[12] United Nations.Report of the Special Rapporteur on the situation of human rights in Myanmar, Yanghee Lee. A/HRC/28/72. 23 March 2015.

[13] Horsey, R. (2011). Ending forced labour in Myanmar engaging a pariah regime. Abingdon, Oxon ; New York, NY : Routledge. 136

[14] UN Security Council. "Report of the Secretary-General on children and armed conflict in Myanmar" (S/2013/258). 1 May 2013.

[15] UN Security Council. "Report of the Secretary-General on children and armed conflict in Myanmar" (S/2013/258). 1 May 2013.

[16] United Nations. "Situation of human rights in Myanmar, Note by the Secretary-General". A/70/412. 6 October 2015.

[17] Hnin Yadana Zaw and Soe Zeya Tun. "Spike in demand for child labour-As construction booms in Myanmar, one in five children aged 10 to 17 go to work instead of to school", Mercury (Durban, South Africa), April 25, 2016.

[18] Nirmal Ghosh. "Myanmar's first civilian President since 1962 - Public expectations of reforms are high as Htin Kyaw and Cabinet members are sworn in". Straits Times, The (Singapore). 31 March 2016.

[19] United Nations. "Report of the Secretary-General,Addendum, Multistakeholder consultations on financing for development". A/60/289/Add.1. 23 August 2005.

[20] "United Nations.Report of the Special Rapporteur on the situation of human rights in Myanmar, Yanghee Lee". A/HRC/28/72. 23 March 2015.

[21] UN Security Council. "Report of the Secretary-General on children and armed conflict in Myanmar" (S/2013/258). 1 May 2013.

[22] United Nations. "Report of the Special Rapporteur on the situation of human rights in Myanmar, Yanghee Lee". A/HRC/28/72. 23 March 2015.

[23] United Nations. "Annual report of the Special Representative of the Secretary-General for Children and Armed Conflict". A/HRC/31/19. 28 December 2015.

[24] UN Security Council. "Report of the Secretary-General on children and armed conflict in Myanmar" (S/2013/258). 1 May 2013.

[25] United Nations. 7466th meeting Thursday, 18 June 2015, 10 a.m. New York.S/PV.7466. 18 June 2015 